\title{
TAFSIR EMANSIPATORIS: PEMBUMIAN METODOLOGI TAFSIR PEMBEBASAN
}

\author{
Fatkhul Mubin \\ STAI Alhikmah Jakarta \\ fatkhulmubin90@gmail.com
}

\begin{abstract}
ABSTRAK
Tulisan ini bertujuan untuk memaparkan metodologi penasiran emansipatoris sebagai metode penafsiran al-Qur'an yang responsif dengan keadaan sosio-kultural dan tidak terjebak pada kungkungan nalar ideologis-dogmatis. Hal ini dikarenakan diskursus tafsir masih diramaikan oleh penafsiran yang masih fokus pada relasi teks dengan penafsir saja, sehingga lokus sosio-kultural belum terjamah, alih-alih pemecahan masalah sosial yang berbasis teks. Jenis penelitian ini adalah penelitian kepustakaan (library research) dengan pendekatan analisis deskriptif. Sumber data dalam penelitian dibedakan menjadi dua macam, yaitu: primer berupa karya sarjana yang membahasa tentang penafsiran emansipatoris dan sekunder berupa buku-buku dan karya-karya ilmiah yang terkait dengan ilmu dan tafsir al-Qur'an. Penelitian ini menghasilkan kesimpulan bahwa tafsir emansipatoris memperlakukan teks kitab suci dalam ruang refleksi kritis sekaligus diaplikasikan dalam ranah praksis, bukan hanya secara moral tetapi juga struktural. Di sini, teks kitab suci digunakan sebagai alat untuk mempertajam kesadaran nurani dalam melihat, mempersepsikan dan sekaligus memecahkan problem-problem sosial kemanusiaan. Prinsip interpretasi atas teks kitab suci, di sini secara linguistik haruslah bersifat komprehensif dan filosofis. Dan dalam konteks praksis, teks kitab suci secara etik pembebasan harus terrefleksikan dalam kehidupan umat manusia.
\end{abstract}

Keyword: Penafsiran Emansipatoris, Metodologi Tafsir, Problem Sosial 


\begin{abstract}
ABSTRACK
This paper aims to describe the emancipatory methodology of interpretation as a method of interpreting the Qur'an that is responsive to socio-cultural conditions and not trapped in the ideological-dogmatic confines of reasoning. This is because the discourse of interpretation is still enlivened by the interpretation which is still focused on the relation of the text to the interpreter only, so that the socio-cultural locus has not been touched, instead of solving social problems based on text. This type of research is library research with a descriptive analysis approach. Data sources in the study are divided into two types, namely: primary in the form of scholarly work that discusses emancipatory interpretation and secondary in the form of books and scientific works related to the science and interpretation of the Qur'an. This research concludes that the emancipatory interpretation treats the text of the scriptures in a space of critical reflection as well as being applied in the realm of praxis, not only morally but also structurally. Here, the text of the scriptures is used as a tool to sharpen conscience in seeing, perceiving and at the same time solving social problems of humanity. The principle of interpretation of scriptural texts, here linguistically, must be comprehensive and philosophical. And in the context of praxis, the text of the scriptures ethically liberation must be reflected in the lives of humanity.
\end{abstract}

Keyword: Emancipatory Interpretation, Interpretation Methodology, Social Problems 


\section{Pendahuluan}

Wacana metodologi tafsir al-Qur'an selama ini masih terbatas pada relasi teks dan mufassir, belum mencapai level pembenturan secara face to face dengan realitas sosial dan kebudayaan manusia. ${ }^{1}$ Di sisi lain, teks alQur'an dipahami sebagai episentrum sekaligus pemegang legalitas tertinggi, karenanya problematika dalam dimensi kehidupan manusia solusi pemecahan masalahnya tidak boleh berpaling dan harus dikembalikan serta diletakkan di bawah otoritas teks. ${ }^{2}$ Karenanya, permasalahan sosial, politik, ekonomi dan kemanusiaan yang dinamis selalu diselesaikan dengan merujuk pada teks kitab suci yang statis. ${ }^{3}$ Dengan demikian, secara metodologis, tafsir masih kental dengan aroma paradigma teosentris-ideologis yang mengakibatkan tercerabutnya tafsir dari gelanggang realitas persoalan-persoalan kemanusiaan, sehingga pada titik yang ekstrim mengesankan bahwa Tuhan menjadi lebih penting untuk dibela, sementara manusia tetap dibiarkan sengsara.

Hasan Hanafi merupakan salah seorang sarjana Muslim kontemporer yang telah membumikan metodologis tafsir dengan pendekatan ilmu sosial dengan mengusung "jargon" al-Manhaj al-Ijtima'i fi al-Tafsir. ${ }^{4}$ Metodologi tafsir model ini, membuka ruang tumbuh dan berkembangnya model tafsir emansipatoris, suatu model penafsiran yang oleh Khaled Abou el Fadhl mempunyai "daya pembebasan" atau kemampuan untuk "membebaskan" secara metodologis dan praksis. ${ }^{5}$ Arkoun menyatakan, prinsip-prinsip model penafsiran emansipatoris telah dicanangkan oleh Farid Esack dengan hermeneutika pembebasan dan Amina Wadud dengan hermeneutika keseteraan jender. $^{6}$ Dengan demikian, pemanfaatan ilmu-ilmu sosial

${ }^{1}$ Adian Husaini dan Abdurrahman al-Baghdadi, Hermeneutika \& Tasir al-Qur'an (Depok: Gema Insani Press, 2007), Hlm. 3

${ }^{2}$ Khaled M. Abou El Fadl, Atas Nama Tuhan: Otoriter ke Fikih Otoritatif, terj. R. Cecep Luikan Yasin, (Jakarta: PT Serambi Ilmu Semesta, 2003), Hlm. 123.

${ }^{3}$ MK. Ridwan, "Tradisi Kritik Tafsir: Diskursus Kritisisme Penafsiran dalam Wacana Qur'anic Studies”, Jurnal THEOLOGIA, Vol. 28, No. 1 (2017), Hlm. 66.

${ }^{4}$ Devi Muharrom Sholahuddin, "Studi Metodologi Tafsir Hasan Hanafi”, Studia Quranika: Jurnal Studi Quran, Vol. 1, No. 1, Juli 2016, Hlm. 58.

${ }^{5}$ Secara metodologis, tafsir emansipatoris dimaksudkan sebagai tafsir yang membebaskan dari kungkungan nalarteologis-dogmatis yang telah dimapankan oleh suatu otoritas keagamaan atau kekuasaan yang hegemonik. Tafsir ini menggeser wilayah penafsiran dari konteks justifikasi (contexs of justification) kepada konteks penemuanpenemuan baru (contexs of discovery). Dengan perkataan lain, membebaskan tafsir dari sekedar menjadi justifikasi pandangan-pandangan teologi lama yang diskriminatif dan menindas, kepada tafsir yang lebih inovatif dan mencerahkan. Lihat, Khaled Abou el Fadhl, Melawan Tentara Tuhan: Yang Berwenang dan Sewenang-wenang dalam Islam, terj. Kurniawan Abdullah (Jakarta: Serambi Ilmu, 2003), Hlm. 37.

${ }^{6}$ Muhammad Arkoun, Berbagai Pembacaan al-Qur'an, terj. Machasin (Jakarta: INIS, 1997), Hlm. 13. 
membantu penafsir mengurai problem-problem sosial kemanusiaan, tidak dengan menggunakan model penyelesaian dogmatik kerohanian, melainkan sosio-kultural.

Dengan demikian, problem kemiskinan, kebodohan, ketidakadlilan jender, politik yang menindas rakyat kecil, korupsi, rasisme, dan masalahmasalah sosial lain, merupakan masalah yang penting untuk dipecahkan dalam konteks tafsir al-Qur'an. Karenanya, tulisan ini akan memaparkan metodologi emansipatoris dalam penafsiran al-Qur'an untuk memperoleh penafsiran yang responsif dengan keadaan sosio-kultural dan tidak terjebak pada kungkungan nalar ideologis-dogmatis.

\section{TINJAUAN PUSTAKA}

Kitab suci Al-Qur'an memang bersifat interpretatif. Sebagian umat Islam sering berdebat pada perbedaan interpretasi, seperti yang terlihat di dalam dua nalar tafsir di atas. Tetapi, kita sadar bahwa problem umat Islam sekarang bukan sekadar problem interpretasi, tetapi lebih riil, kita sekarang sedang menghadapi suatu realitas sosial yang menindas, timpang, dan tidak manusiawi: terjadi ketidakadilan relasi antara laki-laki dan perempuan, kemiskinan, kebodohan, terpuruknya kaum petani, nelayan, dan buruh, serta masalah-masalah sosial yang lain.

Untuk menghadapi problem-problem sosial yang akut tersebut, pertanyaan mendasar sekarang adalah bagaimana secara konseptual tafsir mesti dibangun? Melampaui dua nalar tafsir di atas-yang tidak punya fungsi di dalam menghadapi problem-problem sosial yang sedang dihadapi umat Islam-maka kita mesti mengarahkan lokus penafsiran teks kitab suci AlQur'an, pertama-tama ke arah problem-problem sosial kemanusiaan. Namun, pilihan langkah ini bukan tanpa masalah. Sebab, bergumul dengan kitab suci, kita selalu dihadapkan dengan suatu kepercayaan umat Islam yang sangat kuat bahwa Al-Qur'an seabadi Tuhan sendiri, ia ada selama Tuhan ada. Kita pun bertanya, mana yang lebih dahulu, firman atau umat manusia? Bukankah firman diwahyukan Tuhan kepada umat manusia? Lalu, dari mana kita mesti memulai usaha penafsiran Al-Qur'an: dari teks atau konteksnya, di tengah problem sosial kemanusiaan sekarang ini? Inilah pertanyaan yang pernah dilontarkan oleh Farid Esack. Dia menghadapi dan mengalami langsung suatu problem kemanusiaan, berupa rezim Apartheid di Afrika Selatan dan eksklusivisme beragama yang terjadi di tanah kelahirannya. Dia pun kemudian bersikap tegas: memilih hermeneutika pembebasan dan pluralisme untuk menghidupan firman Tuhan di bumi kelahirannya. ${ }^{7}$

${ }^{7}$ Hal ini bisa disimak dalam Farid Esack, Qur'an, Liberation \& Pluralism: An Islamic Perspective of Interrelegious Solidarity against Oppression, 1997. Buku ini telah dialihbahasakan ke dalam bahasa Indonesia berjudul Membebaskan yang Tertindas, terj. Watung A. Budiman (Bandung: Mizan, 2000). 
Lebih lanjut, tafsir menjadi penting untuk digerakkan ke arah praksis kehidupan sosial umat. Sehingga, orientasi nalar tafsir tidak lagi bersifat teosentris atau pun ideologis, tetapi bersifat antroposentris. Tafsir yang memilih lokusnya pada problem kemanusiaan dan praktik pembebasan inilah yang oleh Masdar F. Mas'udi diistilahkan dengan nalar tafsir emansipatoris. ${ }^{8}$ Pilihan terminologi emansipatoris, menurutnya tidak terlepas dari sejarah teori kritis. Dalam kritisisme ada dua elemen. Pertama, perhatian realitas material, yaitu sebuah pemikiran yang mempertanyakan ideologi hegemonik yang bertolak pada kehidupan riil dan material atau mempertanyakan hegemoni yang bertolak pada realitas empirik. Kedua, visi struktur (relasirelasi), baik relasi kekuasaan dalam dunia produktif (majikan-buruh), maupun relasi hegemonik, dalam hubungan pemberi dan penerima narasi (ulama-umat), maupun relasi politik (penguasa-rakyat). ${ }^{9}$

Karena mengacu dan bertitik tolak pada realitas permasalahan kemanusiaan kontemporer, maka tafsir emansipatoris ini berparadigma tidak lagi terpaku pada pembelaan terhadap Tuhan-karena memang Tuhan tak perlu pembelaan kita - tetapi yang lebih utama adalah secara praksis membangun komitmen terhadap berbagai problem sosial kemanusiaan. Komitmen ini diwujudkan dalam bentuk aksi sosial dalam rangka membangun dan menegakkan nilai-nilai keadilan, kesetaraan dan kemanusiaan. Sehingga, gerakannya ke arah praksis pembebasan manusia; bukan dari kungkungan dogmatisme maupun ideologi, tetapi dari struktur sosial politik yang menindas, yang dengan transparan telah memunculkan kemiskinan, kebodohan, marjinalisasi perempuan, dan problem-problem sosial lain. Tafsir emansipatoris dengan demikian, berikrar menghidupkan elan vital gerakan sosial yang bergerak pada problem-problem sosial kemanusiaan. Secara integral, tafsir emansipatoris tidak berhenti pada pembongkaran teks, tetapi teks dijadikan sebagai sarana pembebasan. Sebab, dominasi realitas tidak hanya pada wilayah wacana, tetapi juga pada ranah yang bersifat bersifat riil dan materiil. ${ }^{10}$ Terlebih adanya kesadaran bahwa peran al-Qur'an adalah sinar bagi sistem kehidupan yang adil, beradab dan berperikemanusiaan.

Orang menuntut agar Al-Qur'an dijadikan sebagai referensi moral dan daya gugah. Namun, di tengah riuhnya tuntutan tersebut, muncul ambivalensi, yaitu intensitas ritual keagamaan menjadi sangat romantik dan marak, namun dalam kehidupan sehari-hari belum mampu melahirkan

\footnotetext{
${ }^{8}$ Masdar F. Mas'udi, "Paradigma dan Metodologi Islam Emansipatoris" Kata Pengantar dalam Veri Verdiansyah, Islam Emansipatoris Menafsir Agama untuk Praksis Pembebasan (Jakarta: P3M, 2004), Hlm. xviii.

${ }^{9}$ Masdar F. Mas'udi, "Paradigma dan Metodologi Islam Emansipatoris", Hlm. 94.

${ }^{10}$ Masdar F. Mas'udi, "Eksplorasi Paradigma dan Metodologi Islam Emansipatoris", Makalah, 2002.
} 
kesalehan diri, apalagi kesalehan sosial. Kehidupan beragama tampak meriah dalam rutinitasnya, namun tanpa disertai dengan keprihatinan dan tanggung jawab sosial. Karenanya yang nampak, agama hanya sebatas sebagai medan penyelamatan personal, tidak sebagai keberkahan sosial. Tuhan, dengan sifat kasih dan sayangnya, tidak (di)hadir(kan) dalam ruang problem sosial. Padahal, agama tanpa tanggung jawab sosial, kata Muslim Abdurrahman, sama artinya dengan pemujaan belaka. Sebab, hanya dengan tanggung jawab sosial, agama dengan semangat profetiknya akan terintegrasikan dengan problematika sosial yang nyata. Di dalam problem sosial itulah seseorang justru akan menemukan basis ketakwaannya dalam bentuk praksis solidaritas sosial kemanusiaan. ${ }^{11}$ Inilah makna juga yang dimunculkan oleh Ali Asghar Engineer dalam rumusan teologi pembebasannya. ${ }^{12}$

\section{METODE}

\subsection{Desain Penelitian}

Desain penelitian merupakan langkah yang harus ditempuh dalam perencanaan dan pelaksanaan penelitian, yang terdiri atas:

\subsubsection{Pendekatan Penelitian}

Penelitian ini menggunakan pendekatan kualitatif. Pendekatan kualitatif menitikberatkan analisis terhadap data deskriptif yang berupa kata-kata tertulis atau lisan dari orang-orang dan perilaku yang diamati. ${ }^{13}$

\subsubsection{Jenis penelitian}

Jenis penelitian yang digunakan oleh penulis adalah penelitian kepustakaan (library research) dengan menelaah buku-buku yang berkaitan dengan pokok-pokok permasalahan dari analisis literatur ini dihasilkan data yang dikehendaki untuk ditelaah secara mendalam. ${ }^{14}$

\footnotetext{
${ }^{11}$ Muslim Abdurrahman, Islam Transformatif (Jakarta: Pustaka Firdaus, 1995), Hlm. 198.

12 Dalam teologi pembebasan lebih menekankan pada praksis daripada teoritisasi metafisis yang mencakup hal-hal yang abstrak dan konsep-konsep yang ambigu. Praksis yang dimaksud adalah sifat liberatif dan menyangkut interaksi dialektis antara "apa yang ada" dan "apa yang seharusnya". Menafsirkan tauhid bukan hanya sebagai keesaan Tuhan, namun juga sebagai kesatuan manusia yang tidak akan benar-benar terwujud tanpa terciptanya masyarakat yang adil. Selengkapnya, lihat Asghar Ali Engineer, Islam dan Teologi Pembebasan, terj. Agung Prihantoro (Yogyakarta: Pustaka Pelajar, 1999).

${ }^{13}$ Lexy J. Moeloeng, Metodologi Penelitian Kualitatif (Bandung: Remaja Rosdakarya. 2001), Hlm. 3.

${ }^{14}$ MoHlm. Nasir, Metode Penelitian (Jakarta: Bumi Aksara, 2000), Hlm. 213.
} 


\subsection{Sumber Data}

Dalam penelitian ini penulis menggunakan beberapa sumber data, kategori sumber data tersebut berdasarkan isinya ada dua macam:

\subsubsection{Sumber Data Primer}

Data primer merupakan data yang hanya bisa didapatkan dari sumber otentik (asli) atau pertama. ${ }^{15}$ Dalam penelitin ini, sumber primer penulis adalah karya-karya sarjana yang membahas tentang penafsiran emansipatoris.

\subsubsection{Sumber Data Sekunder}

Data sekunder ini mempunyai kegunaan untuk mendukung dan memberikan informasi tambahan kepada data primer. Data sekunder dalam penelitian ini penulis dapatkan dari buku-buku dan karya-karya ilmiah terutama yang terkait dengan ilmu dan tafsir al-Qur'an.

\subsection{Teknik Pengumpulan Data}

Pengumpulan data baik primer maupun sekunder dilakukan dengan membaca, memahami, mengidentifikasi, menganalisis dan membandingkan data yang satu dengan data lainnya yang terdapat dalam sumber data. Setelah data terhimpun, kemudian diklasifikasikan sesuai dengan sifat dalam bab-bab tertentu supaya mempermudah analisis. ${ }^{16}$ Adapun dalam penelitian ini, penulis mengumpulkan data dengan membaca, memahami, mengidentifikasi, menganalisis, dan membandingkan teori-teori yang berkaitan dengan penafsiran emansipatoris.

\subsection{Teknik Analisis Data}

Berdasarkan tujuan penelitian yang ingin dicapai, maka teknik analisis data yang penulis gunakan dalam penelitian ini adalah deskripti dengn tujuan untuk memberikan gambaran tentang subyek penelitian berdasarkan data dari sumber penelitian yang diperoleh dari kelompok subyek yang diteliti dan tidak dimaksudkan pengujian hipotesis. ${ }^{17}$

\subsubsection{Metode Deskriptif}

\footnotetext{
${ }^{15}$ Jonathan Sarwono, Metodologi Penelitan Kuantitatif dan Kualitatif (Yogyakarta: Graha Ilmu, 2006), Hlm. 123.

${ }^{16}$ Winarno Surahmah, Metode Penelitian Survey (Jakarta: LP3S, 1993), Hlm. 139.

${ }^{17}$ Saefudin Anwar, Metodologi Penelitian (Yogyakarta: Pustaka Pelajar, 1998), Hlm. 126.
} 
Metode deskriptif adalah suatu cara untuk mendeskripsikan dan menafsirkan apa yang ada, baik mengenai kondisi atau hubungan yang ada, pendapat yang sedang berkembang, proses yang sedang terjadi, akibat efek yang sedang terjadi atau kecenderungan yang sedang marak. $^{18}$

\subsubsection{Analisis konten}

Analisis konten merupakan analisis terhadap maksud dan makna yang terkandung di dalam buku-buku yang menjadi referensi untuk mengetahui ide pokok. Kegunaan analisis konten adalah mengungkapkan isi buku yang mendeskripsikan pengetahuan atau eksplanasi yang ditunjukkan penulis saat menulis buku tersebut. ${ }^{19}$

\subsubsection{Metode induktif}

Adalah tahapan untuk mendapatkan kesimpulan yang dimulai dari sesuatu yang khusus kepada sesuatu yang bersifat umum. ${ }^{20}$

\section{PEMBAHASAN}

\subsection{Pendekatan Penafsiran Emansipatoris dan Permasalahannya}

Tuhan mewahyukan al-Qur'an kepada Muhammad Saw bukan sekadar sebagai inagurasi kerasulan, apalagi suvenir atau nomenklatur. Secara praksis, Al-Qur'an bagi Muhammad Saw merupakan inspirasi etik pembebasan yang menyinari kesadaran dan gerakan sosial dalam membangun masyarakat yang sejahtera, adil dan manusiawi. Sebab, tujuan dasar Islam adalah persaudaraan universal, kesetaraan, dan keadilan sosial.

Kontemplasi yang dilakukan Muhammad Saw. di gua Hira, yang kemudian mengantarkan dirinya memeroleh pengalaman agung - menerima wahyu dari Tuhan untuk kali pertama - hakikatnya merupakan refleksi dan transendensi atas kenyataan-kenyataan sosial masyarakat Arab yang timpang saat itu: sistem ekonomi yang memihak kepada golongan kaya, dominasi laki-laki, dan otoritas sosial serta politik memusat di tangan klan-klan yang dominan.

Dengan demikian, Al-Qur'an saat itu terinternalisasi pada diri Muhammad Saw. yang selalu aktif mempersiapkan diri membuka kaca mata analisis sosial dalam merespons realitas sosial, ekonomi dan politik yang dihadapi masyarakat saat itu. Wahyu yang turun masa awal kerasulannya, misalnya, sangat lekat dengan kritik etik sosial—kritik atas orang yang Hlm. 4.

${ }^{18}$ Saropah Faisal, Metode Penelitian Pendidikan (Surabaya: Usaha Nasional, 1994),

${ }^{19}$ Hadi Nawawi, Metode Penelitian Sosial (Yogyakarta: Gajah Mada University Press, 1998), Hlm. 95.

${ }^{20}$ M. Nizar, Metode Penelitian (Jakarta: Ghalia Indonesia, 1998), Hlm. 63. 
mengakumulasi kekayaan dengan tanpa batas (Qs. Al-Takâtsur: 1-8), larangan menghardik anak yatim dan menelantarkan orang miskin (Qs. AlDhuhâ: 6-10) — ketimbang corak kritik teologis. Hal ini menunjukkan betapa transformasi sosial yang dilakukan Muhammad Saw., tidak lepas dari kemampuannya dalam membaca problem-problem sosial yang dihadapi masyarakat saat itu. Dan dengan demikian, artinya bahwa Al-Qur'an yang diwahyukan kepadanya tidak lahir dari ruang hampa yang kedap dari problem sosial, ekonomi dan politik yang melilit masyarakat saat itu.

Kini, lima belas abad telah berlalu. Al-Qur'an telah terkodifikasi ke dalam satu mushhaf dan satu teks standar. Lalu, bagaimana kita mesti memahaminya dalam konteks problem sosial yang kompleks yang kita hadapi sekarang?

Pertanyaan ini jelas berkaitan dengan problem metodologi penafsiran. Perlu disadari, bahwa sebagai wahyu yang telah mengalami tekstualisasi, AlQur'an telah menjadi teks tertutup. Mohamed Arkoun menyebutnya sebagai corpus resmi. Artinya, jumlah ayat dan surahnya tidak lagi bisa bertambah, pun apalagi dikurangi. Namun, pembacaan terhadapnya, sebagai proses penggalian makna-makna konseptual yang bermanfaat bagi kehidupan umat manusia, tentu selaiknya tidaklah pernah tertutup dan atau hanya dimonopoli oleh suatu komunitas tertentu secara hegemonik. Sebab, sebagai teks, AlQur'an secara inhern tidaklah akan pernah bisa 'berbicara' sendiri, ia mesti disuarakan dengan 'pembacaan-pembacaan' secara produktif. "Al-Qur'ân bayna daftayi al-mushhaf lâ yanthiqu, wa innamâ yatakallamu bihi al-rijâl," kata Imam Ali. Pembacaan yang produktif ini tentu mengandaikan adanya metodologi tafsir.

Sejauh ini dalam studi keilmuan Islam klasik, sebagai suatu metode dalam memahami kitab suci all-Qur'an, ilmu tafsir termasuk dalam lingkup ilmu keislaman yang bersifat single tradition; tidak dihubungkan secara langsung dengan ilmu-ilmu sosial. Kitab-kitab 'Ulûm al-Qur'ân yang selama ini menjadi standar dalam ilmu tafsir, secara umum bicara dalam konteks problem teks. Belum memasuki ranah problem konteks sosial di mana penafsir berada. ${ }^{21}$ Lalu, pada era sekarang muncul pemikir-pemikir baru yang merumuskan metodologi baru dalam pembacaan teks kitab suci. Sekadar menyebut contoh, Riffat Hassan membangun hermeneutik al-Qur'an feminis dengan menyusun tiga prinsip interpretasi: (1) linguistic accuracy, yaitu melihat terma dengan merujuk pada semua leksikon klasik untuk memperoleh apa yang dimaksud dengan kata itu dalam kebudayaan di mana ia dipergunakan, (2) criterion of philosophical consistency, yaitu melihat

\footnotetext{
${ }^{21} \mathrm{Hal}$ tersebut di atas, dapat dilihat dari berbagai kitab 'Ulûm al-Qur'ân yang selama ini menjadi standar, misalnya Mannâ' al-Khalîl al-Qaththân, Mabâhits fì 'Ulûm al-Qur'ân

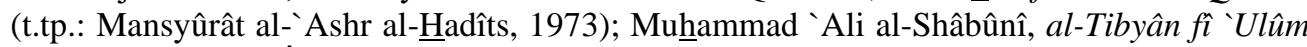
al-Qur'ân (Beirut: Âlam al-Kutub, t.th).
} 
penggunaan kata-kata dalam Al-Qur'an itu secara filosofis konsisten dan tidak saling bertentangan, dan (3) ethical criterion, yakni bahwa praktik etis sesungguhnya harus terefleksikan dalam Al-Qur'an. ${ }^{22}$

Amin al-Khuli (w. 1966 M.) ketika berhadapan dengan teks alQur'an, membangun wilayah hermeneutik teks dari unthinkable menjadi thinkable. Ia memperlakukan teks al-Qur'an sebagai kitab sastra Arab terbesar (Kitâb al-`Arabiyyah al-akbar), sehingga analisis linguistik-filologis teks merupakan upaya niscaya untuk menangkap pesan moral al-Qur'an. Dalam usahanya ini, al-Khuli sama sekali tidak bermaksud menyejajarkan status al-Qur'an dengan teks sastra kemanusiaan, tetapi ia bermaksud menemukan angan-angan sosial kebudayaan al-Qur'an dan hidayah yang terkandung dalam komposisinya sebagaimana telah ditangkap oleh Nabi Muhammad SAW. ${ }^{23}$ Pandangan al-Khuli ini yang kemudian dikembangkan oleh Nashr Hamid Abu Zayd. Dia berpandangan bahwa studi Al-Qur'an haruslah dikaitkan dengan studi sastra dan studi kritis. Studi tentang AlQur'an sebagai sebuah teks linguistik meniscayakan penggunaan studi linguistik dan sastra. Untuk melakukan proyek ini dia mengadopsi teori-teori mutakhir dalam bidang linguistik, semiotik dan hermeneutika dalam kajiannya tentang Al-Qur'an. ${ }^{24}$

Hassan Hanafî (lahir 1935 M.) mengintrodusir sebuah hermeneutik Al-Qur'an yang spesifik, temporal, dan realistik. Menurutnya, hermeneutik Al-Qur'an haruslah dibangun atas pengalaman hidup di mana penafsir hidup dan dimulai dengan kajian atas problem manusia. Interpretasi haruslah dimulai dari realitas dan problem-problem manusia, lalu kembali kepada AlQur'an untuk mendapatkan sebuah jawaban teoretis. Dan jawaban teoretis ini haruslah diaplikasikan dalam praksis. Teori Hanafî ini didasarkan pada konsep asbâb al-nuẑ̂l yang memberikan makna bahwa realitas selalu mendahului wahyu. ${ }^{25}$ Dalam hermeneutik Al-Qur'an semacam ini, ilmu-ilmu sosial kemanusiaan serta unsur triadik (teks, penafsir dan audiens sasaran

${ }^{22}$ Riffat Hassan, "Women's Interpretation of Islam”, dalam Hans Thijsen (ed.), Women and Islam in Muslim Society (The Hague: Ministry of Foreign Affairs, 1994), Hlm. 116.

${ }^{23}$ Selengkapnya lihat, J.J.G. Jansen, The Interpretation of the Koran in Modern Egypt (Leiden: E.J.Brill, 1974). Edisi Indonesia, Diskursus Tafsir Al-Qur'an Modern, terj. Hairussalim dan Syarif Hidayatullah (Yogyakarta: Tiara Wacana, 1997).

${ }^{24}$ Tentang Abu Zayd dalam konteks studi Al-Qur'an baca kajian Moch Nur Ichwan, Meretas Kesarjanaan Kritis Al-Qur'an, Teori Hermeneutika Nasr Abu Zayd (Jakarta: Teraju, 2003). Buku ini berasal dari tesis penulisnya yang ditulis dalam program S2 di Universitas Leiden Nederland dalam bahasa Inggris yang kemudian diindonesiakan oleh penulisnya sendiri.

${ }^{25}$ Hassan Hanafî, Dirasât Islâmiyyah (Kairo: Maktabat al-Anjilu al-Mishriyyah, 1981), Hlm. 69. 
teks) menjadi demikian signifikan. Suatu proses penafsiran tidak lagi hanya berpusat pada teks, tetapi juga penafsir di satu sisi dan audiens di sisi lain.

Dalam konteks problem sosial kemanusiaan, model pembacaan kitab suci yang ditawarkan oleh Hassan Hanafi di atas sungguh menarik. Sebab sejauh ini, pembacaan kitab suci dalam sejarahnya yang amat panjang, tampak masih terasing dari realitas dan problem-problem sosial kemanusiaan. Pada sisi lain, teks kitab suci menjadi pusat dan sekaligus pemegang otoritas yang berkuasa di dalam menentukan suatu paradigma adalah teks, ukuran untuk menyelesaikan problem-problem kehidupan masyarakat adalah teks. Problem sosial, politik, ekonomi dan kemanusiaan, selalu dikembalikan (sebagai bentuk penyelesaian) kepada teks kitab suci. Kerangka berpikirnya tentu bersifat deduktif yang berpangkal pada teks dan realitas harus sesuai dan tunduk kepada teks. Maka, tafsir sebagai metode pembacaan kitab suci dengan demikian masuk di dalam lingkaran "peradaban teks". Ia sangat lekat, meminjam pemetakan Mohamed Abied Al-Jabiri, dengan al-`aql al-bayân atau yang oleh Mohamed Arkoun dimasukkan ke dalam al-`aql al-lâhût sama halnya dengan Kalam, Fikih, Falsafah dan tasawuf, dalam mainstream tradisi keilmuan Islam tradisional. ${ }^{26}$

Dalam lingkaran peradaban teks tersebut, sejarah perkembangan tafsir dalam konteks nalar formatifnya, secara umum setidaknya berkisar pada dua pendulum besar. ${ }^{27}$ Pertama, nalar teosentris. Yaitu penafsiran kitab suci yang dominan memusatkan diri pada tema-tema ketuhanan. Tuhan harus disucikan, diagungkan dan tentu dibela. Maka, ketika bicara mengenai masalah keadilan, maka keadilan yang dimaksud adalah keadilan Tuhan. Ketika bicara soal kasih sayang, maka konteksnya selalu ditarik dalam pengertian kasih sayang Tuhan. Ketika bicara soal kekuasaan dan kebebasan, maka yang muncul adalah kekuasaan dan kebebasan Tuhan. Begitulah seterusnya. Dalam konteks nalar tafsir yang demikian, Tuhan telah diletakkan sebagai subyek yang tampak dirundung banyak masalah, sehingga harus dibela dan diperjuangkan dalam kehidupan umat manusia. Para mufasir dengan segala kemampuannya tampil untuk membela-Nya. Itulah akhirnya, tafsir menjadi bersifat sangat teosentris.

\footnotetext{
${ }^{26}$ Mohamed Arkoun, al-Fikr al-Ushûlî wa Istihhâlah al-Ta'shîl (Beirut: Dar al-Saqi, 2002), Hlm. 308.

${ }^{27}$ Masdar F. Mas'udi, "Rekonstruksi Al-Qur'an di Indonesia”, Makalah yang dipresentasikan pada acara Semiloka FKMTHI di gedung PUSDIKLAT Muslimat NU, Pondok Cabe, Jakarta Selatan, 2003, Hlm. 4. Pemetaan tipologi nalar ini berbeda dengan yang selama ini terjadi dalam aliran-aliran tafsir yang dirumuskan berdasarkan ruang lingkup keilmuan. Misalnya, ada tafsir fiqhi, tafsir sufi, tafsir falsafi, tafsir lughawi, tafsir al-`aqdi, tafsir al-bathini, tafsir bi al-matsur, dan tafsir bi al-ra’yi. Lihat, Muhammad `Ali al-Shâbûnî, al-Tibyân fì 'Ulûm al-Qur'ân (Beirut: Âlam al-Kutub, t.tHlm.); 'Ali al-Ausi, alThabâthabâ'i wa Manhajuhu fî Tafsîrih (Teheran: Mu’âwanah al-Riâsah lil'Alâqah alDaulah fî̀ Mundzimah al-Ấlam al-Islâmî, 1985).
} 
Membesarkan, mensucikan dan mengagungkan Tuhan memang suatu kesadaran yang logis di dalam syariat agama. Namun, bila kemudian sikap ini menyingkirkan kajian atas problem-problem kemanusiaan, maka wacana tafsir hanya dikembangkan dalam mainstream pembelaan dan pengagungan Tuhan. Al-Qur'an dan penafsirannya, akhirnya hanya dipersembahkan untuk Tuhan. Padahal, seperti kita tahu, Al-Qur'an merupakan petunjuk bagi kehidupan umat manusia di dunia ini, bukan untuk Tuhan. Al-Qur'an merupakan inspirasi gerakan pembebasan dalam struktur masyarakat yang menindas, rasis dan ahumanis, bukan sebatas praktik-praktik ritual sebagai bentuk pengagungan Tuhan.

Tafsir era klasik sangat didominasi dengan model tafsir teosentris ini. Polemik di kalangan para teolog Muslim-seputar masalah sifat dan perbuatan Tuhan: apakah manusia bisa melihat-Nya secara langsung kelak di surga, apakah Tuhan mempunyai tangan seperti manusia, Kalam Allah makhluk atau tidak, dan seterusnya - telah mewarnai dengan kental wacana tafsir pada masa itu. Para teolog memperdepatkan masalah-masalah di seputar eksistensi Tuhan. Muktazilah yang sering dianggap sebagai aliran rasionalisme di dalam Islam, pada kenyataannya rasionalisme mereka itu hanya untuk membela keagungan dan kesucian Tuhan, bukan membela problem-problem sosial kemanusiaan yang dihadapi umat Islam pada saat itu. Secara praksis, tafsir saat itu telah mengabaikan persoalan-persoalan sosial kemanusiaan serta menjadi kehilangan spirit pembebasan dalam mengurai problem sosial kemanusiaan tersebut.

Yang kedua, nalar tafsir ideologis. Yakni pembacaan atas kitab suci yang telah berorientasi pada problem-problem manusia, tetapi masih bersifat abstrak dan intelektualis, tidak substansial dan tidak mengacu secara langsung pada problem kemanusiaan yang dihadapi umat. Tafsir ideologis ini berkutat pada pengukuhan atas paham, aliran dan madzhab tertentu, baik itu dalam konteks fikih, teologi maupun tasawuf. Tafsir ideologis ini tidak hanya bersifat teosentris, tetapi yang tampak dominan adalah membela aliran dan madzhab tertentu yang berkembang di dalam sejarah umat Islam. Nalar tafsir ini secara tendensius membela aliran dan keyakinan tertentu yang hidup di dalam masyarakat Islam. Maka, muncullah aliran tafsir Sunni, tafsir Syi`ah, tafsir Muktazilah, begitu juga dalam konteks hukum, muncul tafsir yang membela madzhab-madzhab fikih. ${ }^{28}$

Misalnya, kalangan Syi'ah memaknai surah Al-Rahmân: 19-22, maraj albahraini yalta qiyân, baina humâ barzakhullâ yabghiyân, fabiayyi âlâ

\footnotetext{
${ }^{28}$ Fahd ibn `Abdurrahnân ibn Sulaimân al-Rûm, Ittijâhât al-Tafsîr fì Qarn al-Râbi 'Asyr (Riyad: Maktabah Rusyd, 2002), jilid I. Buku ini mengkaji tafsir-tafsir yang lahir pada abad 14 hijriaHlm. Dari studi ini terlihat bahwa nalar tafsir-tafsir tersebut masih terkungkung di dalam konteks aliran fikih dan teologi. Perdebatan yang kuat masih memperjuangkan kesucian, keadilan dan keagungan Tuhan.
} 
irabbikumâ tukadz dzibân, yakhruju minhumal lu’lulu wal marjân-Dia memberikan dua lautan mengalir, yang keduanya kemudian bertemu antara keduanya ada batas yang tidak dilampaui. Dari keduanya keluar mutiara dan marjan", dua lautan dimaknai dengan Ali dan Fatimah; barzakh (batas) adalah Muhammad; mutiara dan marjan adalah Hasan dan Husain. ${ }^{29}$ AlQusyairi menakwilkan ayat yang sama sebagai berikut: Allah menjadikan dua lautan hati, yaitu lautan khauf dan lautan rajâ'. Mutiara dan marjan adalah kondisi psikologis dan rahasia-rahasia spiritual kaum sufi. ${ }^{30}$

Nalar tafsir ideologis maupun teosentris telah terjadi sangat lama dalam sejarah umat Islam, dan melapuk di dalam sistem kesadaran mereka. Dalam rentang waktu yang lama tersebut, tafsir ideologis telah memunculkan pertarungan ideologi dan pertarungan madzhab, baik di dalam bidang teologi, fikih, filsafat maupun tasawuf. Mereka saling rebut ayat kitab suci lalu ditafsirkannya secara ideologis, untuk mengukuhkan paham-paham mereka. Akhirnya, yang muncul adalah apa yang disebut Nashr Hâmid Abû Zayd sebagai qirâ'ah al-mughridhah atau tafsir ideologis (talwîn). ${ }^{31}$ Orang membaca Al-Qur'an secara tendensius, diletakkan dalam kerangka ideologi yang telah dibangunnya terlebih dahulu, tanpa mempunyai pijakan epistemologis yang kuat terhadap gagasan pokok kitab suci. Sehingga, yang tampak seakan-akan ada ayat-ayat Al-Qur'an yang pro aliran Qadariah dan pada sisi lain ada ayat-ayat yang pro aliran Jabariah. ${ }^{32}$ Fakta ini di dalam sejarah bukan hanya akan menampilkan Al-Qur'an dalam kerangka yang ambigu, tetapi bahkan yang lebih telak, menjadikan Al-Qur'an kehilangan elan vital-nya di dalam mengurai dan mencari penyelesaian atas problemproblem kehidupan dan sosial umat manusia.

Meski kedua nalar tafsir tersebut telah berlangsung lama dalam sejarah umat Islam, tetapi tidak memberikan sumbangan penting terhadap proses humanisasi di tengah problem riil masyarakat Muslim, karena keduanya tidak mempunyai konsern dan tidak terkait langsung dengan proses formasi sosial. Peran yang diambilnya, bila kita merujuk pada tradisi fikih yang selama ini telah terbentuk, sebatas pada masalah kontrak sosial antarindividu, belum

\footnotetext{
${ }^{29}$ Muhammad 'Âbid Al-Jâbirî, Bunyah al-'Aql al-'Arabî: Dirâsah Tahlîliyyah Naqdiyyah li Nuzhûm al-Ma`rifah fi al-Tsaqâfah al-'Arabiyyah (Beirut: Al-Markaz alTsaqafi al-'Arabî, 1993), Hlm. 306.

${ }^{30}$ Muhammad 'Âbid Al-Jâbirî, Bunyah al- 'Aql al- 'Arabî. Hlm. 315.

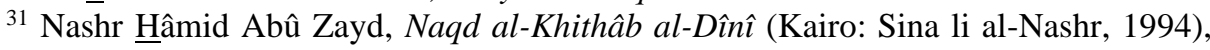
Hlm. 926.

${ }^{32}$ Kajian tentang teologi di dalam Islam, terutama teologi di era klasik, teologi Muktazilah, Asy'ariah, Qadariah dan Jabariah, sesungguhnya tidak bisa dilepaskan dari kajian tentang problem penafsiran atas kitab suci yang mereka lakukan. Hal ini penting disadari karena pertentangan antaraliran di dalam sejarah Islam selalu mengaitkan diri pada dasar pijak yang sama, yaitu teks Al-Qur'an. Ini berarti ada nalar penafsiran dan pilihan ayat yang berbeda sehingga melahirkan paham-paham yang beragam.
} 
masuk ke ranah bangunan sistem sosial, politik dan kekuasaan yang membentuk formasi sosial.

\subsection{Paradigma Tafsir Emansipatoris dengan Metodologi Tafsir}

Dalam konteks terjadinya ambivalensi tersebut, tafsir yang secara metodologis selama ini hanya berada dalam lingkaran islamic studies yang kental dengan nalar teosentris (al-`aql al-lâhûtî̀), maka meniscayakan adanya kebutuhan terhadap ilmu-ilmu sosial. Maka, tafsir tidak lagi dikungkung dalam peradaban teks, tetapi mesti dirajut dengan peradaban ilmu (science) yang oleh Arkoun disebut sebagai al-`aql al-târihĥ wa 'ilmiy. Sebab, memahami fenomena dan problem sosial yang dihadapi manusia kontemporer sangat terkait dengan ilmu budaya, yang mengungkap masalah yang terkait dengan ide dan nilai yang dianut di dalam kelompok masyarakat; dan ilmu sosial yang terkait dengan sistem dan interaksi kelompok di dalam masyarakat. Untuk mengetahui dan mengurai problem sosial kemanusiaan di tengah masyarakat, kita bukan menggunakan analisis kerohanian yang abstrak, seperti yang selama ini lebih sering terjadi, tetapi haruslah dengan menggunakan kacamata analisis sosial. Hal ini penting untuk merumuskan pemahaman keagamaan mengenai problem kemanusiaan, merefleksikannya secara kritis, menteoritisasikan dalam bentuk perubahan, dan aksi perubahan itu sendiri. ${ }^{33}$

Salah satu contoh adalah ketika orang menguraikan masalah kemiskinan. Kemiskinan merupakan suatu hal yang dibenci di dalam agama Islam. Tindakan menelantarkan kaum miskin, oleh agama Islam juga dipandang sebagai tindakan yang tidak etis. Namun, sebagian orang seringkali menggunakan analisis kerohanian di dalam mengurai dan menjelaskan problem kemiskinan, yakni dikaitkan dengan soal kualitas ketakwaan umat yang lemah. Lemahnya ketakwaan inilah yang diklaim sebagai penyebabnya. Diagnosa seperti ini jelas membingungkan. Kita tahu bahwa masalah kemiskinan merupakan masalah sosial dan kongkret, namun penyebabnya tiba-tiba dengan mudah dituduhkan pada soal ketakwaan yang abstrak. Kita tahu bahwa sekarang ini mesjid didirikan di mana-mana-Pak Harto bahkan pernah membuat proyek mesjid Pancasila di seluruh Indonesia-, acara pengajian diselenggarakan di berbagai tempat, acara santapan rohani bahkan telah menjadi trend dalam dunia entertaint, tapi toh kenyataannya kemiskinan justru semakin kuat melilit umat Islam.

Apa sesungguhnya penyebab kemiskinan dan bagaimana cara penyelesaiannya? Diagnosa dengan jalan kerohanian di atas, tampaknya

${ }^{33}$ Masdar F. Mas'udi, "Paradigma dan Metodologi Islam Emansipatoris" Pengantar dalam Veri Verdiansyah, Islam Emansipatoris Menafsir Agama untuk Praksis Pembebasan, Hlm. xvii. 
memang tidak relevan, atau bahkan memang keliru. Sebab, kemiskinan lebih merupakan problem sosial. Sebagai problem sosial, maka masalah kemiskinan akan terlihat jelas faktor-faktor penyebabnya, bila dilihat dengan analisis sosial. Pada kenyataannya, penyebab kemiskinan bukan hanya soal ketakwaan-yang abstrak tersebut, tetapi menyangkut struktur relasi sosial di masyarakat yang timpang. Maka, di sini akan terlihat bahwa kemiskinan terjadi bisa disebabkan karena adanya monopoli ekonomi yang dilakukan oleh kalangan konglomerat, kebijakan ekonomi yang dilakukan oleh penguasa yang tidak memihak kepada kepentingan masyarakat umum, dan atau bisa juga tidak adanya sikap dinamis dan progresif di kalangan umat itu sendiri.

Dalam konteks ini, maka penyelesaian masalah kemiskinan, tentu tidak cukup dengan pendekatan kerohanian yang abstrak-lewat adagium-adagium yang tampak religius, seperti sabar, tawakal, lapangdada menerima takdir Tuhan, dan seterusnya. Penyelesaian semacam ini jelas hanya akan menyesatkan dan mengasingkan agama serta kitab sucinya dari problem riil yang dihadapi umat manusia. Agama hanya jadi opium bagi pemeluknya. Nah, ilmu-ilmu sosial dalam tafsir emansipatoris dapat membantu kita di dalam mendiagnosa dan memahami problem sosial kemanusiaan yang dihadapi umat manusia tersebut.

Dalam contoh kasus kemiskinan di atas, dapat diuraikan dari kasus perkasus. Bila kemiskinan disebabkan oleh adanya monopoli di kalangan kongklomerat dengan menguasai sentra-sentra ekonomi, maka penyelesaiannya adalah perlu adanya sistem distribusi ekonomi yang adil, baik dalam bentuk pembayaran pajak maupun membangun jaringan kerja antara industri kecil dan kalangan konglomerat, sehingga kekayaan tidak akan hanya berputar di kalangan konglomerat saja. Yang kedua, bila kemiskinan disebabkan oleh adanya kebijakan pemerintah yang tidak adil, yang justru berpihak pada pengusaha besar, maka dalam faktor ini harus ada kritik struktural terhadap pemerintah di dalam pembuatan kebijakankebijakannya terkait dengan masalah-masalah ekonomi. Ketiga, bila masalah kemiskinan terjadi disebabkan oleh tidak produktifnya masyarakat di dalam menjalani hidup, maka perlu adanya penyadaran tentang perlunya semangat hidup yang dinamis dan progresif dengan berbagai pelatihan dan pengembangan skill.

Analisis semacam ini bisa terjadi tidak lepas dari bantuan ilmu-ilmu sosial. Dengan memanfaatkan ilmu-ilmu sosial, penafsir kitab suci ql-Qur'an akan mampu menemukan dan mengurai problem-problem sosial kemanusiaan, bukan dengan model penyelesaian kerohanian, tetapi dengan analisis sosial dan kultural. Merefleksikan problem-problem tersebut secara sosial, moral, dan teologis, lalu menteoritisasikan perubahan sebagai landasan aksi pembebasan. 


\subsection{Kerangka Metode Tafsir Emansipatoris}

Tafsir emansipatoris, secara konseptual menempatkan Al-Qur'an dalam ruang sosial di mana penafsir berada, dengan segala problematika kehidupannya, sehingga sifatnya tidak lagi terkait dengan sosio-kultural kearaban dan abstrak - yang sebagiannya secara tradisional terekam di dalam asbâb al-nuẑ̂l - tetapi bersifat spesifik dan praksis yang dikaitkan langsung dengan problem-problem sosial kemanusiaan yang dihadapi masyarakat, pada saat di mana proses tafsir tersebut dilakukan. ${ }^{34}$ Kasus yang dialami oleh Farid Esack yang kemudian dia membangun hermeneutika pembebasan dan pluralisme, dan Amina Wadud Muhsin yang membangun hermeneutika kesetaraan jender, adalah dua contoh yang baik dalam masalah tersebut.

Dalam kerangka ini, kita harus mampu mengubah pandangan "normatif" atas teks kitab suci al-Qur'an menjadi rumusan "teoretis" (teori ilmu). ${ }^{35}$ Misalnya, dalam memahami ayat-ayat tentang orang fakir miskin, secara tekstual seringkali kita hanya melihatnya sebagai kelompok yang harus dikasihani dan berhak menerima zakat-sedekah (Qs. Al-Taubah [9]: 60) dan sebagai peminta-minta yang tidak boleh dihardik (Qs. Al-Dhuha [93]: 10). Dengan pendekatan teoretis (meminjam teori-teori sosial), sebagaimana dicontohkan di atas, kita akan mengetahui kalangan fakir miskin secara lebih real, lebih faktual, sesuai dengan kondisi sosial, ekonomi dan kultural.

Penafsiran Al-Qur'an, di sini lalu pertama-tama bersifat exegesis, yaitu mengeluarkan wacana dari Al-Qur'an (reading out) dan kemudian eisegesis, yaitu memasukkan wacana 'asing' ke dalam Al-Qur'an (reading into). ${ }^{36}$ Mengeluarkan wacana dari Al-Qur'an maksudnya adalah merumuskan masalah-masalah moral sosial di dalam Al-Qur'an. Misalnya, soal kemiskinan, kebodohan, jender, rasialisme, diungkap dari dalam teks kitab suci Al-Qur'an. Kemudian, secara teoretik konseptual, problem-problem tersebut direfleksikan secara kritis dengan menggunakan analisis ilmu-ilmu sosial. Dengan cara inilah, problem-problem sosial kemanusiaan tersebut bisa diurai secara komprehensif, praksis dan riil. Dan di sinilah kita akan menemukan elan pembebasan Al-Qur'an.

Ketika mendengarkan suara adzan yang dikumandangkan, sebagai norma religius, kita bukan sekadar perlu mendengarkannya. Tetapi, juga harus merefleksikannya ke dalam norma sosial. Panggilan suci yang mengagungkan Tuhan tersebut, secara implisit dalam konteks norma sosial dan historis, menurut Raof Khoury, berarti: berilah sanksi kepada para lintah

\footnotetext{
${ }^{34}$ Louis Brenner (ed.), Muslim Identity and Social Change in Sub-Saharian Africa, 1993, Hlm. 5-6).

${ }^{35}$ Kuntowijoyo, Paradigma Islam (Bandung: Mizan, 1991), Hlm. 284.

${ }^{36}$ Farid Esack, "Contemporary Religious Thought in South Africa and The Emergence of Qur'anic Heremeneutical Notions”, dalam ICMR., Vol. 2, no. 2, Desember 1991.
} 
darat yang tamak! Tariklah pajak dari mereka yang menumpuk-numpuk kekayaan! Sitalah kekayaan para tukang monopoli yang mendapatkan kekayaan dengan cara mencuri! Sediakanlah makanan untuk rakyat banyak! Bukalah pintu pendidikan lebar-lebar dan majukan kaum wanita....berikan kebebasan, bentuklah majelis syura yang mandiri dan biarkan demokrasi yang sebenar-benarnya bersinar. ${ }^{37}$

\subsection{Tafsir Emansipatoris dan Isu-isu Kontemporer}

Proses tersebut menjadikan gerakan tafsir tidak lagi bersifat top-down, yang berangkat dari refleksi (teks) ke praksis (konteks), tetapi sebaliknya bersifat bottom up, yaitu dari bawah ke atas: dari praksis (konteks) menuju refleksi (teks). Dengan pandangan yang demikian, pengertian "konteks" teks kitab suci tidak hanya dilihat dalam konteks struktur teks (siyâqq al-kalâm), juga tidak hanya dalam pengertian konteks di mana teks tersebut diturunkan (siyâq al-tanzîl). Namun, pengertian konteks juga dipahami dalam ruang sosial budaya di mana penafsir hidup dengan pengalaman budaya, sejarah dan sosialnya sendiri. Sebab, pada saat itu, penafsir tidak hanya berhadapan dengan teks kitab suci, tetapi dia juga - dan ini yang lebih pentingberhadapan dengan realitas sosial, sebagai teks sosial yang selalu hidup dan berkembang. ${ }^{38}$

Dalam kerangka ini, pemahaman atas konsep asbâb al-nuzûl bukan hanya dalam pengertian tradisional yang selama ini dipahami-yaitu sebab turunnya ayat Al-Qur' an yang diriwayatkan para sahabat dari Nabi Sawtetapi secara konseptual juga dalam pengertian problem dan realitas kultural, sosial, ekonomi dan politik pada saat ayat diturunkan. Dengan cara yang demikian ini, kita bisa mengurai problem kultural, sosial, ekonomi dan politik yang terjadi di masyarakat Arab saat Al-Qur'an diturunkan dengan analisis ilmu-ilmu sosial. Lalu, dikaitkan dengan problem-problem sosial, ekonomi dan politik yang terjadi di tengah kehidupan penafsir saat ini. Di sinilah, secara komprehensif kita akan merumuskan mengenai problem kemanusiaan dan cara menyelesaikannya.

Dengan demikian, hal yang mendasar dalam tafsir emansipatoris adalah mengenai tujuan dari penafsiran. Di sini, sebagaimana dalam hermeneutika pembebasan Hassan Hanafi, Al-Qur'an dipahami secara spesifik, tematik, dan temporal. Penafsiran Al-Qur'an haruslah berdasarkan atas pengalaman hidup di mana penafsir hidup dan dimulai dari kajian atas problem-problem manusia yang muncul pada saat itu. Sebab, pada dasarnya, realitas

37 Raif Khoury, al-Thahârah al-Qawmi al-`Arabî, Nahnu Hummatuh wa Mukammiluh, dikutip oleh Asghar Ali Engineer, dalam Islam dan Teologi Pembebasan, Hlm. 5.

${ }^{38}$ Islah Gusmian, Khazanah Tafsir Indonesia, dari Hermeneutika hingga Ideologi (Jakarta: Teraju, 2003), Hlm. 248-9. 
mendahului wahyu, sebagaimana yang kita lihat dalam konsep asbâb alnuzûl. Maka, interpretasi haruslah bertolak dari realitas, lalu kembali kepada wahyu yang secara teoretis sebagai sinar pembebasan, dan kemudian harus berujung pada tindakan praksis. ${ }^{39}$

Maka, dalam kasus ini kita harus mengubah pemahaman atas tematema pokok dalam Al-Qur'an yang "a-historis" menjadi "historis". Misalnya, selama ini, kisah-kisah dalam Al-Qur'an dipahami secara a-historis. Padahal, maksud Al-Qur'an mengisahkan cerita tersebut agar kita berpikir historis. Misalnya, kisah tentang penindasan Fir'aun terhadap bangsa Israel, hanya dipahami pada konteks zaman itu. Padahal, kaum yang tertindas ada di sepanjang zaman, termasuk saat ini, saat kita hidup. Penyembahan berhala yang dilakukan oleh kaum Nabi Ibrahim, bukan hanya terjadi pada saat itu, tetapi juga terjadi di sepanjang zaman. Bahkan, berhala-berhala pada era sekarang semakin berkembang; misalnya berhala itu dalam bentuk kekuasaan, kapital, pemikiran dan yang lain.

Setelah itu, dalam konteks memahami dasar-dasar tindakan moral juga mesti diubah: dari cara berpikir "subjektif" ke arah cara berpikir "objektif". Misalnya, konsep moral tentang tujuan menunaikan zakat, Al-Qur'an menegaskan sebagai "pembersihan" harta dan jiwa kita (Qs. Al-Taubah [9]: 103), atau dalam konteks ancaman. Misalnya adalah sebuah hadis yang diriwayatkan oleh Imam Muslim, "Mâ min shahibi kanzin la yuaddî zakâtahu illâ uhmia 'alaihi fî nâri jahannama, fayuj'alu shafâ'inha fatukwâ bihâ janbahu wa jabhatuhu-seseorang yang menyimpan hartanya, tidak dikeluarkan zakatnya, akan dibakar dalam neraka jahanam. Baginya akan dibuatkan setrika dari api, lalu dipakai menyetrika lambung dan dahinya." ${ }^{40}$ Jelas, perintah itu arahnya adalah sisi subjektif. Tetapi, sisi objektif tujuan penunaian zakat adalah demi kesejahteraan sosial. Dari arah objektif inilah lalu bisa kita kembangkan pada kasus-kasus yang lain, seperti larangan menumpuk kekayaan, menghardik orang miskin dan menyia-nyiakan anak yatim.

Terkait dengan ini, formulasi wahyu yang bersifat "umum" mesti dipahami dalam konteks "spesifik" dan "empiris". Misalnya, Al-Qur'an mengecam orang-orang yang menumpuk-numpuk kekayaan secara pribadi sehingga kekayaan berputar hanya di kalangan kaum kaya. Kita perlu mengartikan pernyataan wahyu tersebut pada pengertiannya yang spesifik dan empiris. Ini berarti kita mesti menerjemahkan pernyataan itu ke dalam

${ }^{39}$ Hassan Hanafi, Dirâsah Islâmiyyah (Kairo: Maktabah Al-Anjilu al-Mishriyyah, 1981), Hlm. 69. HurairaHlm.

40 Shậh $\underline{h}$ Muslim, Kitâb Zakâh, hadis nomor 1648, diriwayatkan dari Abu

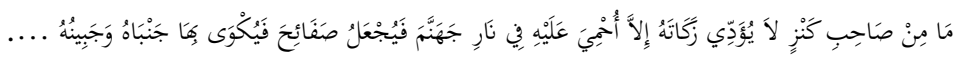


realitas sekarang, yaitu adanya monopoli dan oligopoli dalam kehidupan ekonomi dan politik; adanya penguasaan kekayaan oleh kalangan tertentu di lingkungan elite yang berkuasa. Dan juga memahami wahyu yang bersifat "individual" ini ke arah yang "struktural". Dalam contoh kasus di atas, kekayaan yang hanya memusat pada satu orang atau kelompok, sesungguhnya bukanlah semata-mata masalah individual tetapi juga menyangkut masalah struktural, yaitu kebijakan-kebijakan yang tidak membela kepentingan rakyat kecil.

\section{KESIMPULAN}

Dari uraian tersebut di atas, terlihat bahwa tafsir emansipatoris memperlakukan teks kitab suci dalam ruang refleksi kritis sekaligus diaplikasikan dalam ranah praksis, bukan hanya secara moral tetapi juga struktural. Di sini, teks kitab suci digunakan sebagai alat untuk mempertajam kesadaran nurani dalam melihat, mempersepsikan dan sekaligus memecahkan problem-problem sosial kemanusiaan. Prinsip interpretasi atas teks kitab suci, di sini secara linguistik haruslah bersifat komprehensif dan filosofis. Dan dalam konteks praksis, teks kitab suci secara etik pembebasan harus terrefleksikan dalam kehidupan umat manusia.

Cara memahami wahyu sebagaimana diuraikan di atas akan mampu mengungkap signifikansi yang implisit di dalam teks Al-Qur'an, yang tak terkatakan di dalam struktur wacana teks. Kita akan mampu memunculkan tema-tema sosial yang selama ini menjadi problem sosial masyarakat dan belum diangkat dengan tegas di dalam wacana tafsir secara komprehensif dengan basis ilmu sosial. Maka, tafsir emansipatoris bukan hanya mengurai masalah ketidakadilan, deskriminasi jender, pembebasan umat yang tertindas, baik secara ekonomi, politik, maupun ras. Tetapi, tafsir emansipatoris juga akan membuka pintu dalam pembahasan masalah korupsi, suap, money politics, hibah kepada pejabat, kolusi, nepotisme, perburuhan, petani, nelayan dan masalah-masalah sosial lainnya, sekaligus bagaimana gerakan penyelesaiannya. 


\section{DAFTAR PUSTAKA}

Abdurrahman, Muslim Abdurrahman. 1995. Islam Transformatif. Jakarta: Pustaka Firdaus.

Al-Ausi,'Ali, 1985. Al-Thabâthabâ'i wa Manhajuhu fì Tafsîrih. Teheran: Mu âwanah al-Riâsah lil`Alâqah al-Daulah fî Mundzimah al-Â'lam al-Islâmî. Al-Jâbirî, Muhammad 'Âbid. 1993. Bunyah al-'Aql al-'Arabî: Dirâsah Tahlîliyyah Naqdiyyah li Nuzhûm al-Ma'rifah fi al-Tsaqâfah al-'Arabiyyah. Beirut: Al-Markaz al-Tsaqafi al-'Arabî.

Al-Qaththân, Mannâ' al-Khalîl. 1973. Mabâhits fỉ 'Ulûm al-Qur'ân .t.tp.: Mansyûrât al-`Ashr al-Hadîts.

Al-Rûm, Fahd ibn `Abdurrahmmân ibn Sulaimân. 2002. Ittijâhât al-Tafsîr fì Qarn al-Râbi `Asyr. Riyad: Maktabah Rusyd

Al-Shâbûnî, Muhammad 'Ali. T.th. Al-Tibyân fì 'Ulûm al-Qur'ân. Beirut: Âlam al-Kutub.

Anwar, Saefudin. 1998. Metodologi Penelitian. Yogyakarta: Pustaka Pelajar. Arkoun, Mohamed. 2002. Al-Fikr al-Ushûlî wa Istihâhlah al-Ta'shîl. Beirut: Dar al-Saqi.

\section{INIS.}

1997. Berbagai Pembacaan al-Qur'an, terj. Machasin. Jakarta:

El Fadl, Khaled Abou. 2003. Melawan Tentara Tuhan: Yang Berwenang dan Sewenang-wenang dalam Islam, terj. Kurniawan Abdullah. Jakarta: Serambi Ilmu.

. 2003. Atas Nama Tuhan: Otoriter ke Fikih Otoritatif. terj. R. Cecep Luikan Yasin. Jakarta: PT Serambi Ilmu Semesta.

Engginer, Asghar Ali 1999. Islam dan Teologi Pembebasan, terj. Agung Prihantoro Yogyakarta: Pustaka Pelajar.

Esack, Farid. 1991. "Contemporary Religious Thought in South Africa and The Emergence of Qur'anic Heremeneutical Notions", ICMR., Vol. 2, No. 2, Desember.

Esack, Farid. 2000. Membebaskan yang Tertindas, terj. Watung A. Budiman. Bandung: Mizan.

Faisal, Saropah. 1994. Metode Penelitian Pendidikan. Surabaya: Usaha Nasional

Gusmian, Islah. 2003. Khazanah Tafsir Indonesia, dari Hermeneutika Hingga Ideologi. Jakarta: Teraju.

Hanafi, Hassan Hanafi. 1981. Dirâsah Islâmiyyah. Kairo: Maktabah AlAnjilu al-Mishriyyah.

Hassan, Riffat. 1994. "Women's Interpretation of Islam", dalam Hans Thijsen (ed.), Women and Islam in Muslim Society The Hague: Ministry of Foreign Affairs. 
Husaini, Adian dan Abdurrahman al-Baghdadi. 2007. Hermeneutika \& Tasir al-Qur'an. Depok: Gema Insani Press.

Ichwan, Moch Nur. 2003. Meretas Kesarjanaan Kritis Al-Qur'an, Teori Hermeneutika Nasr Abu Zayd. Jakarta: Teraju.

Jansen, J.J.G, 1974. The Interpretation of the Koran in Modern Egypt. Leiden: E.J.Brill,

Kuntowijoyo. 1991. Paradigma Islam. Bandung: Mizan.

Mas'udi, Masdar F. 2003. "Rekonstruksi Al-Qur'an di Indonesia", Makalah Semiloka FKMTHI, Hlm. 4. Jakarta Selatan.

Mau'udi, Masdar. 2004, "Paradigma dan Metodologi Islam Emansipatoris" Kata Pengantar dalam Veri Verdiansyah, Islam Emansipatoris Menafsir Agama untuk Praksis Pembebasan. Jakarta: P3M.

Moelong, Lexy J. 2001. Metodologi Penelitian Kualitatif. Bandung: Remaja Rosdakarya.

Nasir, Moh. 2000. Metode Penelitian. Jakarta: Bumi Aksara.

Nawawi, Hadi. 1998. Metode Penelitian Sosial. Yogyakarta: Gajah Mada University Press.

Nizar, M. 1998. Metode Penelitian. Jakarta: Ghalia Indonesia.

Ridwan, MK. 2017. "Tradisi Kritik Tafsir: Diskursus Kritisisme Penafsiran dalam Wacana Qur'anic Studies". Jurnal THEOLOGIA, Hlm. 6 Vol. 28 , No. 1.

Sarwono, Jonathan. 2006. Metodologi Penelitan Kuantitatif dan Kualitatif. Yogyakarta: Graha Ilmu.

Sholahuddin, Devi Muharrom. 2016. " Studi Metodologi Tafsir Hasan Hanafi”. Studia Quranika: Jurnal Studi Quran, Hlm. 58, Vol. 1, No. 1, Juli.

Surahmah, Winarno. 1993. Metode Penelitian Survey. Jakarta: LP3S.

Zayd, Nashr Hâmid Abû. 1994. Naqd al-Khithâb al-Dîn̂. Kairo: Sina li alNashr, 1994. 